\title{
Construction Industry Needs for Vocational High School Graduates
}

\author{
Nurlita Pertiwi \\ Department OF Civil and Planning Education \\ Universitas Negeri Makassar \\ Makassar, Indonesia \\ nurlita.pertiwi@unm.ac.id
}

\author{
Irma Aswani Ahmad \\ Department Civil and Planning Education \\ Universitas Negeri Makassar \\ Makassar, Indonesia \\ irmalakampi@gmail.com
}

\begin{abstract}
The purpose of this study is to identify the competencies of vocational high school graduates and describe strategies for the achievement of these outcomes. This study formulates particular competencies required by the construction industry. The research method is quantitative. Data of competence graduates obtained by distributing questionnaires at 45 construction industries in Makassar. These industries are represented by three types of consultants which are planners, supervisors, and contractors. Furthermore, data competency achievement strategies obtained by questionnaire at five vocational technologies education experts. The construction industry needs analysis using descriptive methods. The strategy analysis was carried out by the method of analytical hierarchy process (AHP). The results showed that the primary competence of graduates, especially in attitude is confidence in the completion of work. In knowledge aspects, the graduates must have procedural knowledge about constructions method. In the aspect of skill, graduates should have the creativity in problem-solving. External strategy for achieving competence of graduates based on expert opinion is the development of teaching factory in schools, while internal strategy is development learning model.
\end{abstract}

\section{Keywords-construction industry; competence; strategy}

\section{INTRODUCTION}

Vocational Secondary Education as a subsystem of national education plays an essential role in preparing qualified human resources professionals. Vocational High School (SMK) should be able to prepare its graduates as a candidate for a professional workforce. The Vocational Education is defined as a method used by schools, especially at secondary school level to organize their curriculum so that students can develop skills. These methods provide supplies for students entering the labor market strategically [1]. Also, there are six objectives of vocational education [2] The first objective is providing necessary skills and expertise for the individual. The second objective of the vocational education is meeting the needs of the organizational structure in various areas of work followed by providing equal opportunities for many people or support an increase in the welfare of society. The next objective is vocational education function as the media in improving social indicators and the national economy. Vocational education also as externalities, which can actively support social life, namely a reduction in crime rates, increased prosperity and increased social interaction.
The last objective is supporting the quality improvement of service on providers.

Specifically, in Indonesia, development of vocational curriculum is based on the National Competence Indonesia (SKKNI). Vocational graduates should be able to be absorbed by the industry. Regulation of the Ministry of Education and Culture of the Republic of Indonesia Number 54 The year 2013 about the Graduate Competency Standards Elementary and Secondary Education. Qualification Capabilities Vocational Graduates was set in Table 1.

TABLE I. QUALIFICATION OF VOCATIONAL GRADUATES

\begin{tabular}{|l|l|}
\hline \multicolumn{1}{|c|}{ Aspect } & \multicolumn{1}{c|}{ Qualification } \\
\hline Attitude & $\begin{array}{l}\text { Behavior reflects the attitude of the faithful, noble, } \\
\text { knowledgeable, confident, and responsible for } \\
\text { efficiently interacting with the social and natural } \\
\text { environment as well as in placing a reflection of the } \\
\text { nation in the association world. }\end{array}$ \\
\hline Knowledge & $\begin{array}{l}\text { Knowing factual, conceptual, procedural, and } \\
\text { metacognitive in science, technology, art, and culture } \\
\text { with human insight, national, state, and civilization - } \\
\text { related causes and effects of phenomena and events. }\end{array}$ \\
\hline Skill & $\begin{array}{l}\text { Having the ability to think and act of effective and } \\
\text { creative in the realm of the abstract and concrete as } \\
\text { the development of learned at school independently. }\end{array}$ \\
\hline
\end{tabular}

The first aspect of competence is the attitude. Many sociologists define that attitude is an intention to act or mental position about a fact or state or a feeling or emotion toward a fact or state.[3]. Knowledge of accurate information that has been organized and evaluated by a human mind and that has shaped actions, beliefs, attitudes, institutions or mental states [4]. Knowledge is an interaction between intelligence (capacity to learn) and situation (opportunity to learn). While the definition of skills as a combination of factors resulting raw, expert, rapid and accurate performance, regarded this as equally applicable to manual operations and mental activities. [5].

Work in construction companies is project-oriented and unique. This requires the use of project management tools and techniques as opposed to conventional management techniques. Project management tools ensure smooth execution of activities [6]. Project management cannot be implemented without the support of a reliable workforce. 
However, the condition of the construction workforce in Indonesia is very worrying. In 2013 there is 6.9 million workforces in construction or approximately $5.7 \%$ of the national workforce. Of these, $4 \%$ of whom are experts, $20 \%$ are skilled workers (skilled labor), and $76 \%$ the rest is unskilled labor (unskilled labor) although it obtained only $10 \%$ had been certified competence.

Individual competence in construction comprises: 1) Occupational skills and knowledge (including functional skills); 2) Health and safety skills and knowledge; 3) Human factors (including self-situational and risk awareness, and communications); 4) Continuous improvement (including positive experience).[7]

Based on the above, the workforce in the construction industry should be able to understand the working system or procedures, both administrative and technical; also, an excellent working attitude as a sense of responsibility and ethics must also be owned by the vocational school graduates. The skill of graduates is also a significant competency is the ability to solve problems carefully courts. These competencies related to the creativity.

The purpose of this study was: to describe the need of construction industry vocational graduates competency in Makassar and to obtain the strategies for the competence achievement of graduates both internally and externally.

\section{METHODS}

This study is a survey research using questionnaire containing questions about the variables that will be studied. The research activities take place in May to July 2016. The variables are attitude, knowledge, and skill. Population in this study are all construction industry in Makassar. Samples determined as much as 45 industries that represent the three types be planner, supervisors, and contractors. Samples were determined using purposive sampling method, i.e., construction industries involving more than ten vocational graduates since the establishment of the business. Data were analyzed by using a scoring method. The higher the score, the higher needs of the construction industry for the competence while the strategy analysis carried out by the method of analytical hierarchy process (AHP). The experts in this study came from vocational technology education experts and professional vocational teachers. AHP questionnaire contains nine of possible answers. Data analyzed using pairwise comparison matrix.

\section{RESUlTS AND DISCUSSION}

\section{A. The Need of Construction Industry Vocational Graduates Competency In Makassar}

The attitude is useful for social environment and the ability to work in teams. The work team should solve most jobs in the construction industry. The construction industry needs the attitude of graduates to have confidence, responsibility, and interaction with the social environment. The result of the score needed is represented in Figure 1.

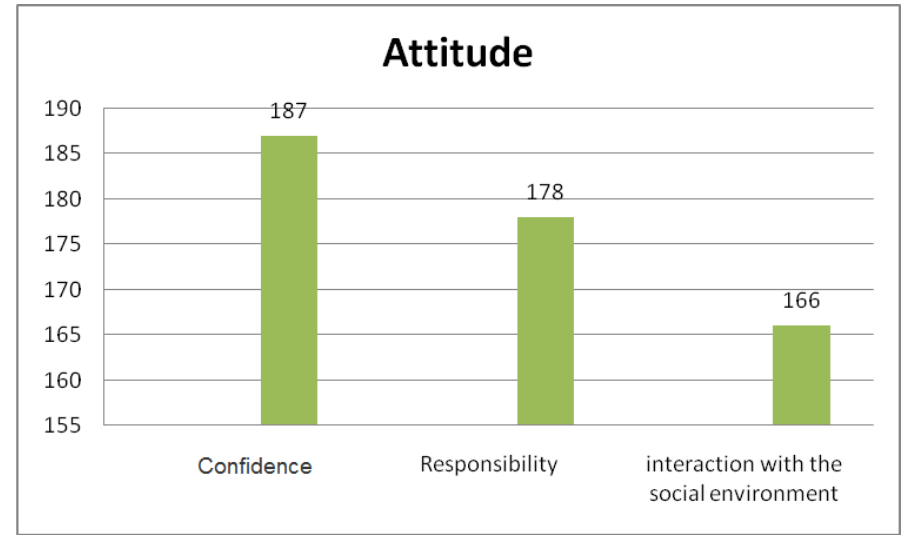

Fig. 1. Needed of construction industry for attitude graduates

Figure 1 shows that the primary competence for aspects of attitude is the confidence with a score of 187 . The second competency is the responsibility (score 178), and the third is the interaction with the social environment (score 166).

An aspect of knowledge is significant for workers in construction. The complicated and confusing job requires precision workers. For example, various conditions must be known in placing concrete in work building. The result of knowledge score needed is represented in Figure 2.

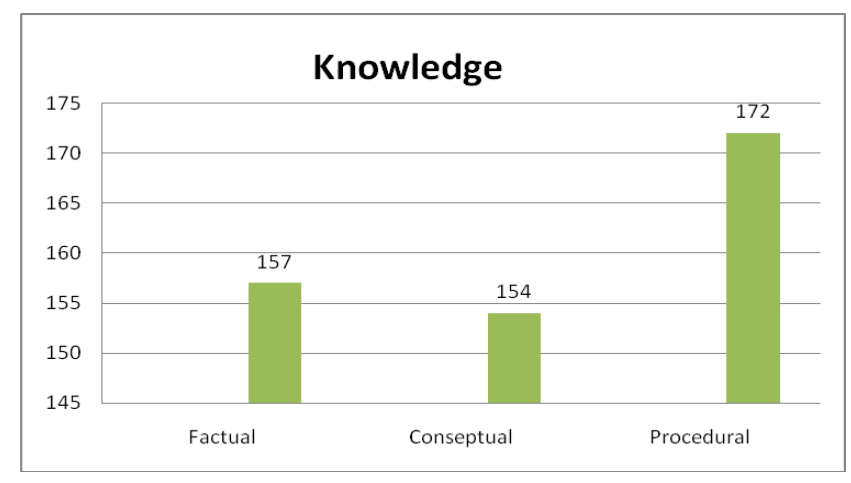

Fig. 2. Needed of construction industry for knowledge graduates

Figure 2 shows that the primary competence for aspects of knowledge is procedural with a score of 172. The second competency is factual (score 157), and the third is conceptual (score 154). It suggests that workers should be able to describe the detail of the work stages. All construction work must comply with the technical requirements prescribed by the state.

Skills are the primary objectives of vocational education. A highly skilled workforce can overcome construction problems quickly so that the work can be completed on time. This is a crucial performance requirement in the construction industry. A score of three indicators of skill is represented in figure 3 .

Figure 3 shows that primary competence for skill aspect is creativity with a score of 181 . The second competency is the ability to think (score 627), and the third is effective action 
(score 156). Creativity characterized by the ability of workers around the limitations that occur in work. Many limitations in construction are due to the late material, weather, equipment and human resources.

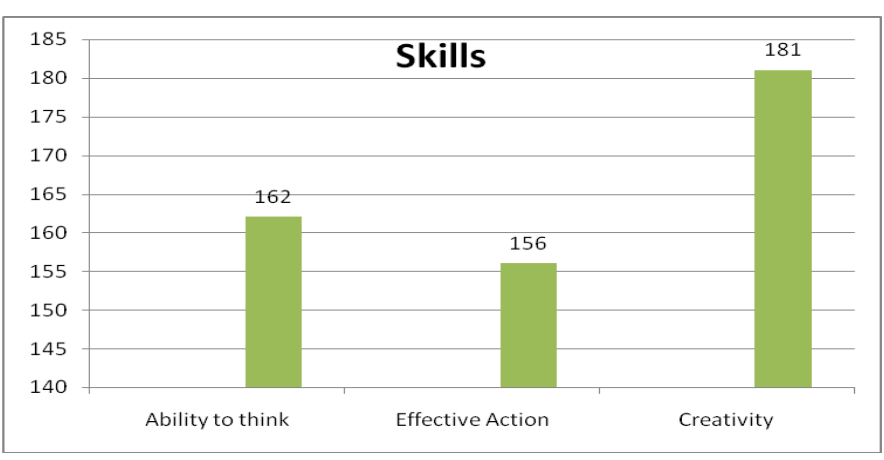

Fig. 3. Needed of construction industry for skill graduates

The industry needs main competence of graduates is the attitude. The score of three variables is represented in Figure 4.

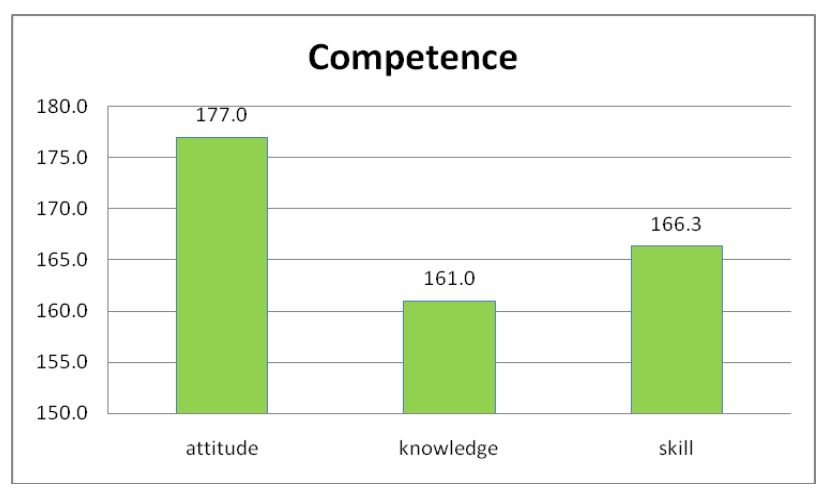

Fig. 4. Needed of construction industry for skill graduates

Figure 4 shows that the primary competency for graduates is an attitude (score 177). The second competency is a skill (score 166), and the third is knowledge (score 161). The figure shows that the primary competence of graduate is working attitude. Within a construction industry, workers must be confident to be able to finish the job. The confidence shown by the workers will be present on time, discipline, understand the terms of employment as well as safety requirements.

\section{B. The Strategies for The Competence Achievement of Graduates}

Early stages of activity to determine the strategy of increasing the competence of graduates is to identify strategies to improve the quality of graduates. This strategy is based on literature review and secondary data from the school. The next stage is the preparation of instruments and expert determination. Filling the instrument by experts followed by recapitulation and analysis data.

The obvious strategy is the involvement of external parties in the school and learning management. There are five for an alternate strategy to achieve confidential of graduate, procedural knowledge, and the creativity. The results of the data analysis of the external strategies that can be done to increase the competence of the graduates are presented in table 2. Based on AHP analysis, it can be revealed that the development of teaching factory in the school is very supportive of competence confidence and creativity of graduates. While to increase the procedural knowledge of graduates, it is necessary to review the curriculum on a regular basis. One form of teaching factory is a production unit in school or learning process that shows the real condition. The ideal teaching factory is to engage industry in the activities of production units. Students can understand the stages of work in the industry with this method.

TABLE II. EXTERNAL STRATEGY FOR THE COMPETENCE ACHIEVEMENT OF GRADUATES

\begin{tabular}{|l|l|l|l|}
\hline \multicolumn{1}{|c|}{ External Strategy } & Confidence & $\begin{array}{c}\text { Procedural } \\
\text { Knowledge }\end{array}$ & Creativity \\
\hline $\begin{array}{l}\text { Industry's role in learning } \\
\text { activities }\end{array}$ & 0.234 & 0.222 & 0.145 \\
\hline $\begin{array}{l}\text { Development of teaching } \\
\text { factory in schools }\end{array}$ & 0.386 & 0.178 & 0.465 \\
\hline $\begin{array}{l}\text { Exploiting the potential of } \\
\text { the area as a learning } \\
\text { resource }\end{array}$ & 0.152 & 0.004 & 0.121 \\
\hline $\begin{array}{l}\text { Development of parental } \\
\text { support }\end{array}$ & 0.002 & 0.145 & 0.165 \\
\hline $\begin{array}{l}\text { Curriculum review } \\
\text { periodically }\end{array}$ & 0.226 & 0.451 & 0.104 \\
\hline
\end{tabular}

Internally, the school can develop a strategy based on the ability of its resources. Analysis of internal strategy presented in table 3.

TABLE III. INTERNAL STRATEGY FOR THE COMPETENCE ACHIEVEMENT OF GRADUATES

\begin{tabular}{|c|c|c|c|}
\hline Internal Strategy & Confidence & $\begin{array}{l}\text { Procedural } \\
\text { Knowledge }\end{array}$ & Creativity \\
\hline Teacher internship & 0.56 & 0.249 & 0.372 \\
\hline $\begin{array}{ll}\begin{array}{l}\text { Learning } \\
\text { development }\end{array} & \text { model } \\
\end{array}$ & 0.3 & 0.516 & 0.459 \\
\hline $\begin{array}{l}\text { Improvement of school } \\
\text { infrastructure }\end{array}$ & 0.14 & 0.235 & 0.169 \\
\hline
\end{tabular}

Table 3 above shows that the teacher internship strategy or provide opportunities for teachers to engage in the construction industry to provide benefits in the development of students' self-confidence. Learning model development improved the procedural knowledge and creativity of graduates. Technology in the construction industry is overgrowing. Working methods and new materials are widely used in modern construction. The teacher internship is the new method to engage the ability of the teacher.

\section{Discussion}

The result illustrates that attitude is the primary capital for vocational school graduates to compete in the construction industry. Specifically, the primary variable is the attitude of self-confidence. The needs of graduates are communication skill, leadership, teamwork skills, initiative, interpersonal 
skills and social networks. Therefore, educators must continue to develop the student attitude. There are four characteristics of confidence, namely: (1) Confidence in their ability to do something. (2) Confidence in ability to follow any initiative itself consistently. (3) Confidence in personal abilities in tackling all obstacles. (4) Confidence in the ability to obtain assistance.[8]

The workforce with high confidence will have the selfesteem of the job. The maintenance and enhancement of selfesteem have always been identified as a fundamental human impulse. Higher confidence will increase the motivation of individuals to give attention to other. Self-confidence can increase the motivation of a person to carry out projects and be able to focus in pursuit of goals and face challenges and temptations that test her destiny. [9]. The strategy to achieve graduate competence, especially for attitude, is teaching factory. These efforts are beneficial to learners in understanding the real industrial activity. However, many of the methods of work cannot be included in a teaching factory because of the complexity of the equipment.

The strategy in school management to increase graduate confidence is an internship. The internship program provides the teacher with a practical knowledge and develops teaching profession and working conditions. Professional teachers must always develop teaching materials by technological developments. The internship program is an effort to improve the teacher knowledge and as a source of material development.

The internship program is a real opportunity to refine and improve their teaching skills in an actual school setting. The results of the in-depth interviews with the principals reveal that internship program is of crucial importance and it has a positive impact on the performance of student-teachers. [10].

Furthermore, the vocational school should develop learning model. Many models can be applied to the school learning environment and the ability of teachers. $F$ the Competence-based vocational education is constructivist learning that prioritizes the development of students' professional knowledge. Professional Personal Concept Theory (PPT) became the basis of personal knowledge of professional development. This model evolved through the interrelated processes of internalization and socialization, in which students grow into the existing body of knowledge and collectively shared norms, values and beliefs professionals from the domain of work.[11]

Based on the results of the research, all stakeholders in education that is public, private and government agencies should establish a good cooperation in creating a skilled workforce. The construction industry in Indonesia will proliferate with the support of local professional workforce.

\section{CONCLUSION}

The construction industry needs main competence of graduates is attitude In, In Attitude aspect, graduates should have confidential in the completion of work. In knowledge aspects, the graduates must have procedural knowledge about constructions method. In the aspect of skill, graduates should have the creativity in problem-solving. There are two right strategies to achieve competence graduate. External strategy for achieving competence of graduates based on expert opinion is the development of teaching factory in schools, while internal strategy is development learning model.

\section{REFERENCES}

[1] Y. Shavit and W. Muller, "Vocational secondary education," Eur. Soc., vol. 2, no. 1, pp. 29-50, 2000.

[2] V. Gasskov, Managing vocational training systems: A handbook for senior administrators. International Labour Organization, 2000.

[3] M. Fugate, A. J. Kinicki, and B. E. Ashforth, "Employability: A psychosocial construct, its dimensions, and applications," J. Vocat. Behav., vol. 65, no. 1, pp. 14-38, 2004.

[4] P. R. Ehrlich et al., "Knowledge and the environment," Ecol. Econ., vol. 30, no. 2, pp. 267-284, 1999.

[5] J. Winterton, F. Delamare-Le Deist, and E. Stringfellow, Typology of knowledge, skills, and competences: clarification of the concept and prototype. Office for Official Publications of the European Communities Luxembourg, 2006.

[6] H. Garbharran, J. Govender, and T. Msani, "Critical success factors influencing project success in the construction industry," Acta Structilia, vol. 19, no. 2, pp. 90-108, 2012.

[7] P. T. (Firm), "Competence in construction," 2014.

[8] M. D. Duerden and P. A. Witt, "The impact of direct and indirect experiences on the development of environmental knowledge, attitudes, and behavior," J. Environ. Psychol., vol. 30, no. 4, pp. 379-392, 2010.

[9] M. Breit, M. Vogel, F. Häubi, F. Märki, and M. Raps, "4D design and simulation technologies and process design patterns to support lean construction methods," Tsinghua Sci. Technol., vol. 13, pp. 179-184, 2008.

[10] S. Parveen and N. Mirza, "Internship program in education: effectiveness, problems and prospects," Int. J. Learn. Dev., vol. 2, no. 1, pp. 487-498, 2012.

[11] H. Schaap, E. De Bruijn, M. F. Van der Schaaf, and P. A. Kirschner, "Students' personal professional theories in competence- based vocational education: the construction of personal knowledge through internalisation and socialisation," J. Vocat. Educ. Train., vol. 61, no. 4, pp. 481-494, 2009. 